\title{
Decomposition and nutrient release from fresh and dried pine roots under two fertilizer regimes
}

\author{
Kim H. Ludovici and Lance W. Kress
}

\begin{abstract}
Root decomposition and nutrient release are typically estimated from dried root tissues; however, it is unlikely that roots dehydrate prior to decomposing. Soil fertility and root diameter may also affect the rate of decomposition. This study monitored mass loss and nutrient concentrations of dried and fresh roots of two size classes $(<2$ and 2-5 mm) over a 12-month period in fertilized and control plots in a 13-year-old loblolly pine (Pinus taeda L.) plantation. Nutrient content was calculated and used to assess the effects of fertilization, root size, and initial condition (hydration) on nutrient release rates. Roots that grew and decomposed in fertilized plots had higher concentrations and greater total release of $\mathrm{N}, \mathrm{P}, \mathrm{K}$, and $\mathrm{Mg}$ than roots in control plots, but $\mathrm{C}$ concentrations and mass loss rate were not significantly different between roots in fertilized plots and those in control plots. Very fine roots $(<2 \mathrm{~mm})$ had higher concentrations of $\mathrm{N}, \mathrm{P}$, and $\mathrm{Ca}$ and faster release rates for $\mathrm{C}, \mathrm{N}$, and $\mathrm{K}$ than fine roots $(2-5 \mathrm{~mm})$, resulting in greater total release of $\mathrm{C}$ and $\mathrm{N}$. Roots dried prior to decomposition decayed and released $\mathrm{C}, \mathrm{K}, \mathrm{Ca}$, and $\mathrm{Mg}$ at a faster rate than fresh roots. Results indicate that using dried root tissues will overestimate fine root decomposition and nutrient cycling rates.
\end{abstract}

\begin{abstract}
Résumé : La décomposition des racines et la libération des nutriments sont typiquement estimées à partir de tissus racinaires séchés. Cependant, il est peu probable que les racines se déshydratent avant de se décomposer. La fertilité du sol et le diamètre des racines peuvent aussi affecter le taux de décomposition. Cette étude a suivi l'évolution de la perte de masse et de la concentration des nutriments de racines fraîches et séchées appartenant à deux classes de dimension (<2 et $2-5 \mathrm{~mm}$ ). L'étude s'est poursuivie pendant une période de 12 mois dans des parcelles fertilisées et témoins établies dans une plantation de pin à encens (Pinus taeda L.) âgée de 13 ans. Le contenu en nutriment a été calculé et utilisé pour évaluer les effets de la fertilisation et de la dimension et de l'état initial (hydratation) des racines sur le taux de libération des nutriments. La concentration et la libération totale de $\mathrm{N}, \mathrm{P}, \mathrm{K}$ et $\mathrm{Mg}$ étaient plus élevées chez les racines qui se sont développées et décomposées dans les parcelles fertilisées comparativement aux racines dans les parcelles témoins mais aucune différence significative n'a été observée dans la concentration de $\mathrm{C}$ ou le taux de perte de masse. Les racines très fines $(<2 \mathrm{~mm})$ avaient des concentrations de $\mathrm{N}, \mathrm{P}$ et $\mathrm{Ca}$ et des taux de libération plus élevés pour $\mathrm{C}, \mathrm{N}$ et $\mathrm{K}$ que les racines fines $(2-5 \mathrm{~mm})$, ce qui se traduisait par une libération totale plus élevée de $\mathrm{C}$ et $\mathrm{N}$. Les racines séchées avant leur décomposition se sont décomposées et ont libéré $\mathrm{C}, \mathrm{K}, \mathrm{Ca}$ et $\mathrm{Mg}$ plus rapidement que les racines fraîches. Les résultats indiquent que l'utilisation de tissus racinaires séchés entraîne la surestimation des taux de décomposition et de recyclage des nutriments chez les racines fines.
\end{abstract}

[Traduit par la Rédaction]

\section{Introduction}

Nutrient inputs from the atmosphere and soil weathering are key to long-term soil development and ecosystem sustainability, but on an annual basis, nutrient recycling within an ecosystem provides the major source of nutrients for plants (Joslin and Henderson 1987; Fahey et al. 1988). Although fine roots and foliage account for a small percentage of total mature pine stand biomass, they contain roughly a quarter of the stand's nitrogen $(\mathrm{N})$ and phosphorus (P) (Van Lear and Kapeluck 1995). Because fine roots often have higher concentrations of nutrients than current foliage (Meier et al. 1985), and because there is minimal retranslocation of nutri-

Received 14 February 2005. Accepted 27 September 2005.

Published on the NRC Research Press Web site at

http://cjfr.nrc.ca on 19 January 2006.

K.H. Ludovici ${ }^{1}$ and L.W. Kress. USDA Forest Service, Southern Research Station, 3041 Cornwallis Road, Research Triangle Park, NC 27709, USA.

${ }^{1}$ Corresponding author (e-mail: kludovici@fs.fed.us). ents from roots upon senescence (Nambiar 1987; Aerts 1990; Nambiar and Fife 1991), decomposing fine roots are an important source of nutrient recycling (Wells et al. 1975; Persson 1979; Raich and Nadelhoffer 1989; Vogt et al. 1991). Calculations of $\mathrm{N}$ returns to soil from decomposing hardwood fine roots have been estimated to be 54 to $72 \mathrm{~kg} \cdot \mathrm{ha}^{-1} \cdot \mathrm{year}^{-1}$ (Hendrick and Pregitzer 1993).

Using a global data set, Silva and Miya (2001) determined that root chemistry (particularly $\mathrm{Ca}$ and $\mathrm{C} / \mathrm{N}$ ) appeared to be the primary controller of root decomposition rate, while climate and environmental factors played secondary roles. In a study by Fahey et al. (1988), initially high rates of $N$ and $P$ release were observed for fine roots, whereas those nutrients were effectively retained in decaying woody roots. A strong decline in nutrient concentration with an increase in diameter of fine roots has been found for $\mathrm{N}$ and $\mathrm{P}$ in an Abies amabilis (Dougl. ex Loud.) Dougl. ex J. Forbes stand (Vogt et al. 1982), for $\mathrm{N}$ in a range of hardwood and pine forests (McClaugherty et al. 1982; Gordon and Jackson 2000), and for $\mathrm{N}, \mathrm{P}, \mathrm{K}, \mathrm{Ca}$, and $\mathrm{Mg}$ in Pseudotsuga menziesii (Mirb.) Franco (Fogel and Hunt 1983). The inverse relationship between $\mathrm{N}, \mathrm{P}$, and Ca concentration and root diameter was sub- 
Fig. 1. Effects of fertilization on (A) root mass remaining, (B) nitrogen concentration, and (C) phosphorus concentration in loblolly pine roots decomposing in situ over a 12-month period. Root size and initial condition have been averaged by fertilization treatment. Error bars represent one standard deviation, and each data point represents $n=12$.

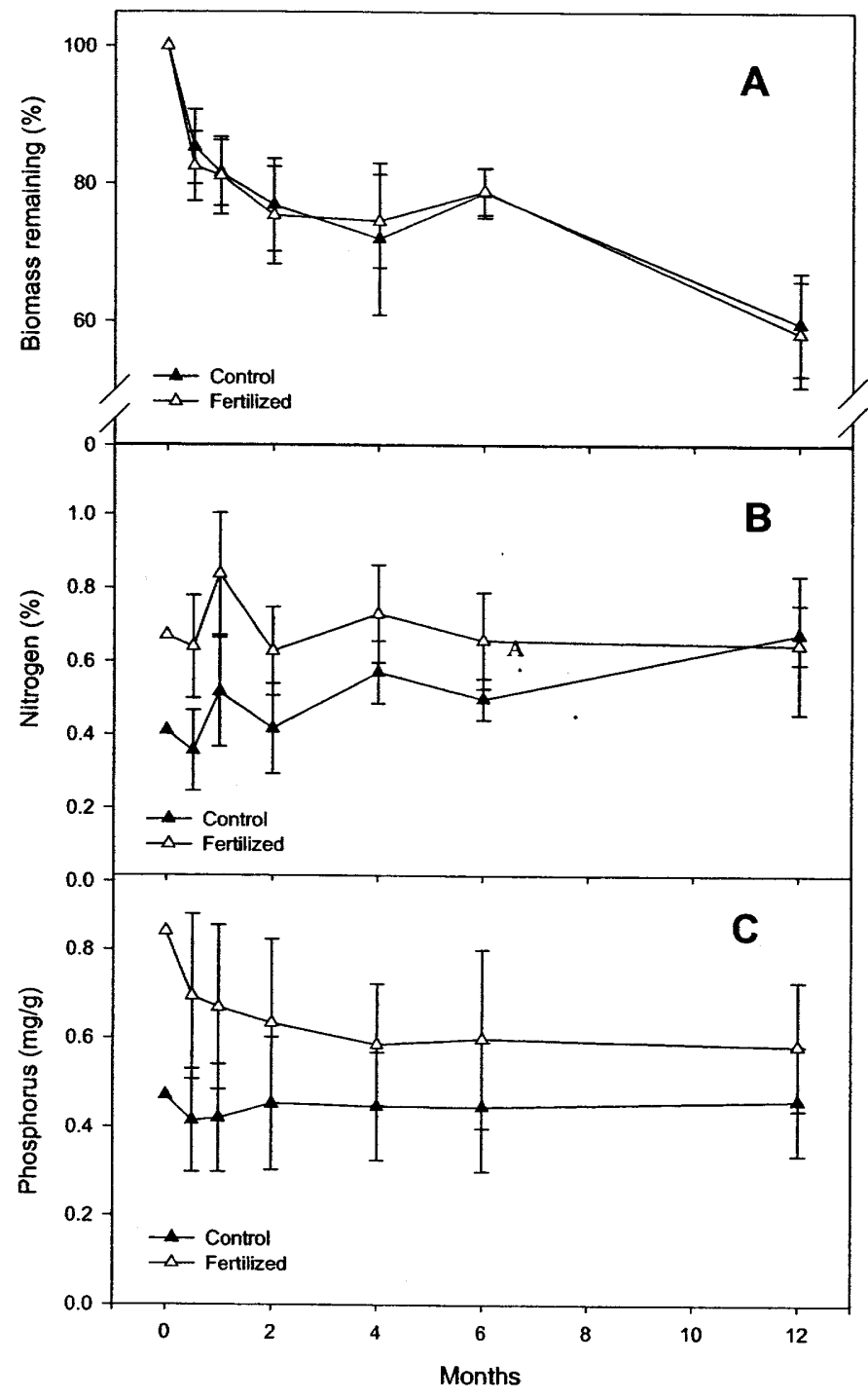

sequently confirmed for Pinus radiata D. Don (Nambiar 1987). The inverse correlation between root diameter and nutrient concentration (Gordon and Jackson 2000) may cause larger diameter roots to decompose at slower rates than smaller diameter roots.

Measuring root decomposition is laborious under controlled conditions and subject to extreme variability from microenvironments in situ. Soil moisture and microbial communities, ionic gradients, and root chemistry and structure could each impact the rate of tissue breakdown and nutrient release. For modeling purposes, soil properties must be uniform and constant, leaving decomposition studies to focus on a variety of root properties. Generally, dried roots are used in decomposition work to ensure stable baseline conditions and mass, but it is unlikely that pine roots in situ dehydrate prior to decomposition, and therefore tissue moisture contents, microbial environments, rhizosphere chemistries, surface areas, and physical integrity will differ between in situ roots and previously dried roots. Fresh roots are expected to decompose more quickly because microbial populations are undisturbed. A direct comparison of fresh and dried roots is needed to more accurately predict and model nutrient release rates.

This 12-month study examined mass loss and nutrient concentrations for dried and fresh roots of two size classes ( $<2$ and $2-5 \mathrm{~mm}$ ), both grown under two site fertilization regimes. The objectives of this study were to (1) quantify biomass and nutrient loss of fine roots with different traits (i.e., $\mathrm{N}$ and $\mathrm{C}$ contents, fresh vs. dried samples, different size classes), and (2) quantify biomass and nutrient loss of roots produced and decomposed under different fertilization regimes. We expected that fresh roots would decompose faster than dried roots, smaller roots would decompose faster than larger roots, and roots grown on fertilized plots would decompose faster than roots on control plots.

\section{Materials and methods}

\section{Site description}

The Southeastern Tree Research and Education Study was established in 1992 in the Georgia-Carolina Sandhills in Scotland County, North Carolina, USA $\left(35^{\circ} \mathrm{N}, 79^{\circ} \mathrm{W}\right)$. A mix of 10 half-sib families of loblolly pine Piedmont selections was hand planted at a $2.2 \mathrm{~m} \times 2.2 \mathrm{~m}$ spacing in March 1985 . The soil is an infertile excessively well drained, sandy, siliceous, thermic Psammentic Hapludult soil of the Wakulla series and had previously supported a stand of longleaf pine (Pinus palustris Mill.). The soil profile has an available water holding capacity of 16 to $20 \mathrm{~cm}(8 \%-10 \%)$ in the upper $2 \mathrm{~m}$, with an average annual precipitation of $1210 \mathrm{~mm}$ and periodic extended droughts during the growing season. Mean annual temperature in the region is $17^{\circ} \mathrm{C}$, with the coldest temperatures in January $\left(0.5^{\circ} \mathrm{C}\right)$ and the warmest in July $\left(32.9^{\circ} \mathrm{C}\right)$.

Sixteen treatment plots, each measuring $50 \mathrm{~m} \times 50 \mathrm{~m}$ (0.25 ha), with $30 \mathrm{~m} \times 30 \mathrm{~m}$ ( $0.15 \mathrm{ha})$ interior measurement plots and $10 \mathrm{~m}$ buffer strips, were established in the 8-yearold pine stand. The experimental design was a factorial combination of two nutrition treatments (control and fertilized) and two irrigation treatments replicated in four randomized complete blocks (Albaugh et al. 1998). Only the control and fertilized plots from three of four blocks were used in this study. Nutrient treatments began in March 1992 and were defined as (1) no-addition controls or (2) fertilized to optimum nutrition. Foliar nutrient status was monitored monthly, and fertilizer additions were made as needed to sustain target nutrient levels. Total nutrient additions between March 1992 and March 1998 were $776 \mathrm{~kg} \cdot \mathrm{ha}^{-1} \mathrm{~N}, 152 \mathrm{~kg} \cdot \mathrm{ha}^{-1} \mathrm{P}$, $337 \mathrm{~kg} \cdot \mathrm{ha}^{-1} \mathrm{~K}, 169 \mathrm{~kg} \cdot \mathrm{ha}^{-1} \mathrm{Ca}, 146 \mathrm{~kg} \cdot \mathrm{ha}^{-1} \mathrm{Mg}, 209 \mathrm{~kg} \cdot \mathrm{ha}^{-1} \mathrm{~S}$, and $3.9 \mathrm{~kg} \cdot \mathrm{ha}^{-1} \mathrm{~B}$ (Albaugh et al. 1998). Complete control of non-pine vegetation had been maintained in all treatment plots since 1992 through a combination of mechanical and chemical (glyphosate) methods.

\section{Sample collection and laboratory analyses}

Roots were collected from six treatment plots in July of 1998. A volume of soil measuring $1 \mathrm{~m}$ wide $\times 1 \mathrm{~m}$ long $\times$ $25 \mathrm{~cm}$ deep (located within the treatment plot, but outside 
Table 1. Probability values from general linear model analyses of model parameters and fit statistics for the full model of biomass and nutrient contents for two sizes of fresh and dry roots decomposing in situ for 12 months in fertilized and nonfertilized stands.

\begin{tabular}{lllllllll}
\hline Source* & $\begin{array}{l}\text { Model } \\
\text { component }^{\dagger}\end{array}$ & $\begin{array}{l}\text { Biomass } \\
\text { remaining }\end{array}$ & $\mathrm{C}$ & $\mathrm{N}$ & $\mathrm{P}$ & $\mathrm{K}$ & $\mathrm{Ca}$ & $\mathrm{Mg}$ \\
\hline $\mathrm{F}$ & $a$ & 0.618 & 0.239 & 0.0001 & 0.0001 & 0.0001 & 0.068 & 0.0001 \\
& $b$ & 0.857 & 0.911 & 0.0004 & 0.0001 & 0.433 & 0.994 & 0.759 \\
& Full model & 0.973 & 0.524 & 0.158 & 0.240 & 0.237 & 0.893 & 0.019 \\
$\mathrm{~S}$ & $a$ & 0.003 & 0.025 & 0.0001 & 0.0001 & 0.0001 & 0.032 & 0.001 \\
& $b$ & 0.001 & 0.017 & 0.006 & 0.067 & 0.020 & 0.915 & 0.719 \\
& Full model & 0.0002 & 0.003 & 0.0001 & 0.0001 & 0.0002 & 0.089 & 0.003 \\
$\mathrm{IC}$ & $a$ & 0.603 & 0.388 & 0.235 & 0.071 & 0.722 & 0.586 & 0.331 \\
& $b$ & 0.001 & 0.040 & 0.100 & 0.090 & 0.0001 & 0.007 & 0.007 \\
& Full model & 0.0001 & 0.052 & 0.009 & 0.069 & 0.0001 & 0.018 & 0.003 \\
$\mathrm{~S} \times$ IC & $a$ & 0.013 & 0.253 & 0.409 & 0.139 & 0.927 & 0.496 & 0.101 \\
& $b$ & 0.791 & 0.236 & 0.412 & 0.341 & 0.737 & 0.576 & 0.175 \\
& Full model & 0.034 & 0.392 & 0.687 & 0.252 & 0.918 & 0.751 & 0.249 \\
$\mathrm{~F} \times \mathrm{S}$ & $a$ & 0.795 & 0.432 & 0.687 & 0.666 & 0.021 & 0.949 & 0.997 \\
& $b$ & 0.984 & 0.254 & 0.080 & 0.053 & 0.584 & 0.115 & 0.260 \\
& Full model & 0.963 & 0.499 & 0.034 & 0.154 & 0.071 & 0.268 & 0.427 \\
$\mathrm{~F} \times$ IC & $a$ & 0.591 & 0.789 & 0.505 & 0.953 & 0.831 & 0.721 & 0.773 \\
& $b$ & 0.729 & 0.136 & 0.149 & 0.065 & 0.284 & 0.208 & 0.626 \\
& Full model & 0.858 & 0.334 & 0.322 & 0.197 & 0.559 & 0.469 & 0.892 \\
\hline
\end{tabular}

${ }^{*} \mathrm{~F}$, fertilization; $\mathrm{S}$, size class; $\mathrm{IC}$, initial condition.

$+a$, intercept or initial value; $b$, slope or rate.

the measurement plot) was removed, sieved, and saved. All roots $<5 \mathrm{~mm}$ diameter were collected, and all other roots were discarded. Live roots were separated into two size classes $(0-2$ and $2-5 \mathrm{~mm}$ in diameter) and cut into $4 \mathrm{~cm}$ lengths. All other identifiable organic material was discarded. The vertical sides of each soil pit were lined with stainless steel flashing to decrease root ingrowth into the decomposition area, before the sieved soil was returned and hand tamped. Soil disturbance was necessary, but there was little soil structure to disrupt in this sand.

Roots from each of the six treatment plots were divided into 24 subsamples for each size class: 7 samples that were to be oven-dried, 7 samples that were to be kept fresh, and 10 additional time-zero samples, which were analyzed for percent moisture, nutrient concentrations, and loss on ignition. Individual root subsamples weighed approximately $2 \mathrm{~g}$ dry mass ( $4 \mathrm{~g}$ fresh mass). Root subsamples that were to be oven-dried were weighed and then placed in a $70{ }^{\circ} \mathrm{C}$ oven for $18 \mathrm{~h}$. Root subsamples that were to be kept fresh were weighed, placed in moist paper towels, and stored overnight at $10^{\circ} \mathrm{C}$. Initial dry masses for these samples were estimated using the percent moisture data calculated from the time-zero root samples. Twenty-four hours after collection, each root subsample was reweighed and returned to the treatment plot from which it originated. Samples were placed at $5-10 \mathrm{~cm}$ depth inside individual plastic ingrowth cores (with a large aperture mesh of approximately $0.5 \mathrm{~cm} \times 0.5 \mathrm{~cm}$, and overall dimensions of $8 \mathrm{~cm}$ diameter $\times 15 \mathrm{~cm}$ long) (MycorrTech ${ }^{\mathrm{TM}}$, Plant Health Care, Inc., Pittsburgh, Pennsylvania ${ }^{2}$ ) positioned vertically within the sieved soil pit. Each plastic core was labeled using a pin flag and randomly assigned to one of the collection times. The decomposing root samples were collected at predetermined intervals $(0.5,1,2,4,6$, and 12 months) after placement in the soil.

Decomposed root samples were recovered by extracting the plastic cores from the soil pit and then sieving the soil. Unwashed samples were placed in labeled plastic bags and transported to the US Forest Service laboratory in the Research Triangle Park for analyses. Remaining root biomass was determined on an ash-free dry-mass basis by drying at $105^{\circ} \mathrm{C}$ for $24 \mathrm{~h}$ and combusting at $550{ }^{\circ} \mathrm{C}$ for $4 \mathrm{~h}$. Samples were ground to pass through an $850 \mu \mathrm{m}$ sieve. Chemical measurements of $\mathrm{C}$ and $\mathrm{N}$ were performed on a Carlo Erba C/N/S analyzer (Fison Instruments, Danvers, Massachusetts). $\mathrm{Ca}, \mathrm{Mg}, \mathrm{P}$, and $\mathrm{K}$ concentrations were determined by inductively coupled plasma spectrophotometry on a Jobin Yvon 2000 ICP (Instruments S.A. Inc., Edison, New Jersey). All masses are reported on an ash-free dry-mass basis. Nutrient contents were calculated by multiplying concentrations with individual calculated dry masses at placement and recollection.

\section{Study design and statistical analyses}

The study included 168 root samples weighing approximately $2 \mathrm{~g}$ each (dry mass). The study was implemented and analyzed as a split-plot design, with the whole plots being the two fertilizer-addition treatments and subplots being the $2 \times 2$ factorial of root size and initial condition.

An exponential equation was used to describe decomposition and nutrient release rates of root materials (Yavitt and Fahey 1982), defined as

[1] $\quad M_{t}=a \mathrm{e}^{-b t}$

where $M_{t}$ was the mass remaining at time $t, a$ was the initial mass or content, and $b$ was the decomposition rate (Bloomfield

\footnotetext{
${ }^{2}$ Use of a trademark product does not indicate an endorsement by the USDA Forest Service.
} 
Fig. 2. Graphical depiction of (A) root mass remaining, (B) nitrogen concentration, and $(C)$ carbon concentration for two diameter size classes of loblolly pine roots decomposing in situ over a 12 month period. Soil fertilization treatment and root initial condition have been averaged by root size class. Error bars represent one standard deviation, and each data point represents $n=12$.

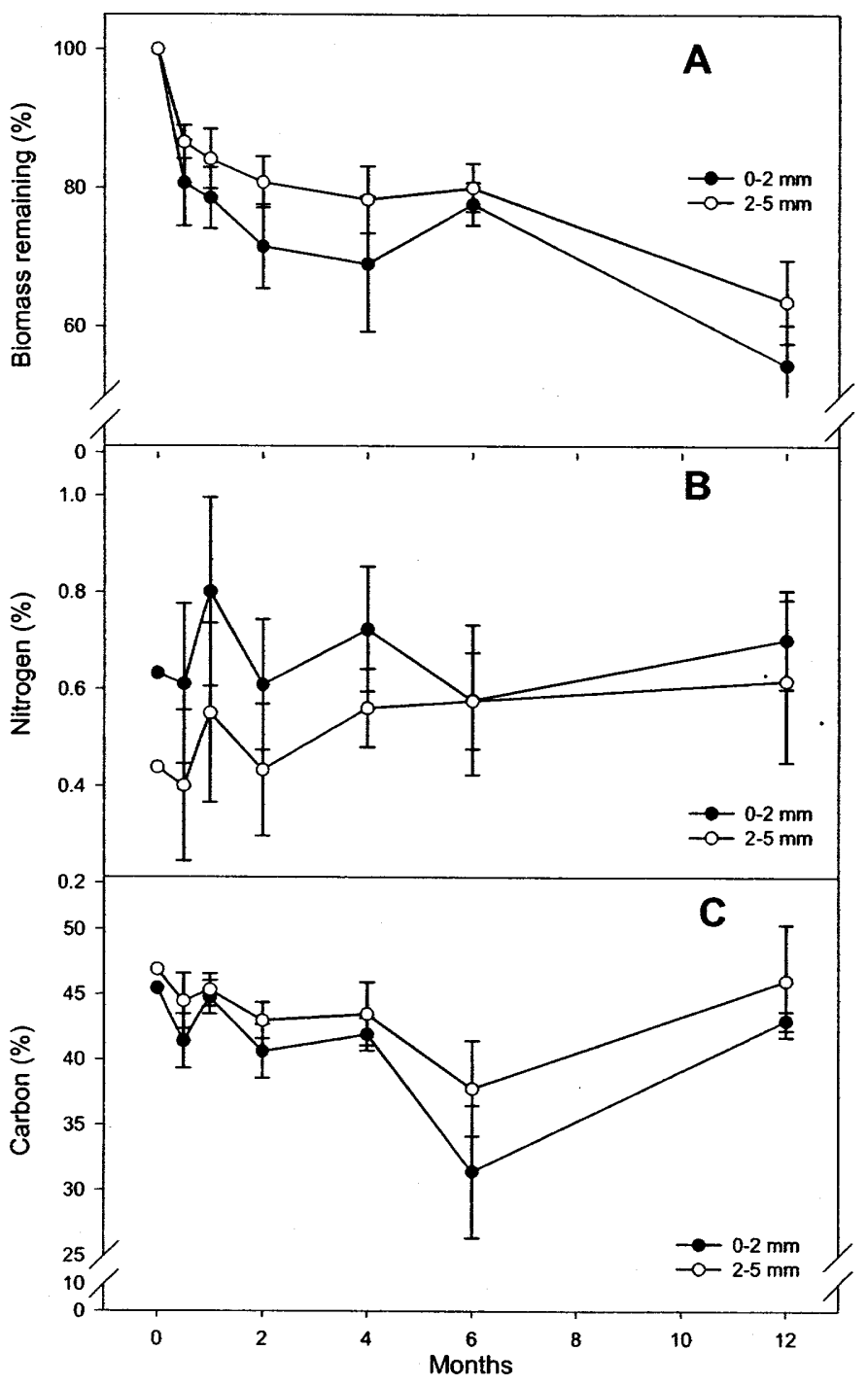

et al. 1993). This model assumes that decomposition is inversely proportional to the amount of material remaining. The utility of this model is that root mass can be predicted as a function of time. These nonlinear models were fit using the PROC NLIN procedure with the GAUSS option (SAS 1985). Wilks' $\lambda$ test was used to compare the exponential equations fit for each nutrient and biomass loss pattern over time. A MANOVA was used to test the coefficients of variables from these response curves to identify significant $(p<$ $0.05)$ differences in initial conditions $(a)$ and decay rates $(b)$.

\section{Results}

\section{Fertilizer treatments}

Pine root mass loss (Fig. 1A) was not significantly impacted by fertilization. Model depiction of mass loss indi-
Table 2. Absolute nutrient release per gram of root tissue decomposed in situ for 12 months.

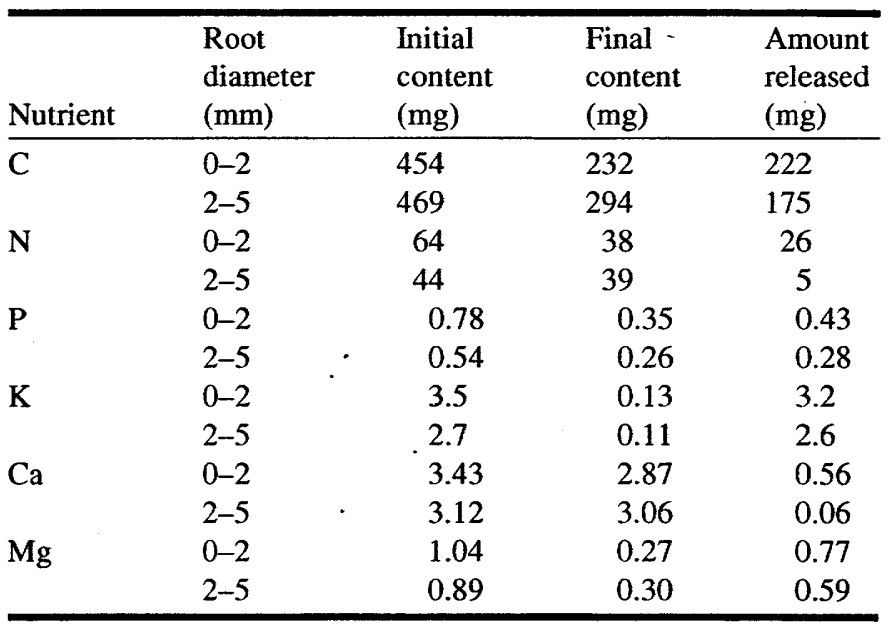

cates no significant differences in decomposition rate or the full model when fertilized plots were compared with controls (Table 1). However, initial concentrations of $\mathrm{N}$ (Fig. 1B), $\mathrm{P}$ (Fig. 1C), $\mathrm{K}$, and $\mathrm{Mg}$ were significantly greater in roots from fertilized plots than in roots from controls. Pine roots from fertilized plots had an initial $\mathrm{N}$ concentration of $0.67 \mathrm{mg} \cdot \mathrm{g}^{-1}$, compared with $0.41 \mathrm{mg} \cdot \mathrm{g}^{-1}$ in control samples. Concentrations of $\mathrm{P}\left(0.84\right.$ vs. $\left.0.47 \mathrm{mg} \cdot \mathrm{g}^{-1}\right), \mathrm{K}\left(3.95\right.$ vs. $\left.2.45 \mathrm{mg} \cdot \mathrm{g}^{-1}\right)$, and $\mathrm{Mg}\left(1.12\right.$ vs. $\left.0.82 \mathrm{mg} \cdot \mathrm{g}^{-1}\right)$ were approximately $40 \%$ greater in fertilized roots than in control samples, respectively. Concentrations of $\mathrm{C}(46.4 \%$ vs. $45.8 \%)$ and $\mathrm{Ca}(3.2$ vs. $3.35 \mathrm{mg} \cdot \mathrm{g}^{-1}$ ) were similar in fertilized and control root tissues.

Root $\mathrm{N}$ contents varied little through time in control plots, but decreased by more than $30 \%$ in fertilized plots. The rate of $P$ release from pine roots was also significantly faster in fertilized plots than in control plots ( $b$ in eq. 1 and Table 1 ), but fertilized roots maintained a greater total $P$ content. Fertilization treatments did not significantly affect release rates of other nutrients.

\section{Root size class}

The initial concentration and content ( $a$ in eq. 1 and Table 1) of all nutrients measured, as well as the mass loss rate and release rate of $\mathrm{C}, \mathrm{N}$, and $\mathrm{K}$ ( $b$ in eq. 1 and Table 1 ) differed between the two root size classes. As expected, very fine roots $(0-2 \mathrm{~mm})$ decomposed faster than fine roots (2$5 \mathrm{~mm}$ ) (Fig. 2A). Very fine roots lost slightly more than $20 \%$ of their mass within the first month of decomposition, while the larger roots lost $20 \%$ of their mass over a 4-month period.

Very fine roots had higher initial concentrations of $\mathrm{N}$ (Fig. 2B), P (0.78 vs. $\left.0.54 \mathrm{mg} \cdot \mathrm{g}^{-1}\right), \mathrm{K}\left(3.5\right.$ vs. $\left.2.7 \mathrm{mg} \cdot \mathrm{g}^{-1}\right)$, $\mathrm{Ca}\left(3.43\right.$ vs. $\left.3.12 \mathrm{mg} \cdot \mathrm{g}^{-1}\right)$, and $\mathrm{Mg}\left(1.04\right.$ vs. $\left.0.89 \mathrm{mg} \cdot \mathrm{g}^{-1}\right)$ than fine roots, while the concentration of $\mathrm{C}$ (Fig. 2C) was greater in $2-5 \mathrm{~mm}$ roots. Release rates of $\mathrm{C}$ and $\mathrm{N}$ contents were significantly greater in very fine roots than in fine roots ( $b$ in eq. 1 and Table 1). Absolute contents of $\mathrm{N}, \mathrm{P}, \mathrm{K}, \mathrm{Ca}$, and $\mathrm{Mg}$ released per gram of root tissue were of greater magnitude for $0-2 \mathrm{~mm}$ roots than for $2-5 \mathrm{~mm}$ roots (Table 2). 
Fig. 3. Effects of two initial root tissue moisture contents on (A) root mass remaining, (B) nitrogen contents, and (C) carbon contents of loblolly pine roots decomposing in situ over a 12month period. Soil fertilization treatments and root size class have been averaged by initial condition. Error bars represent one standard deviation, and each data point represents $n=12$.

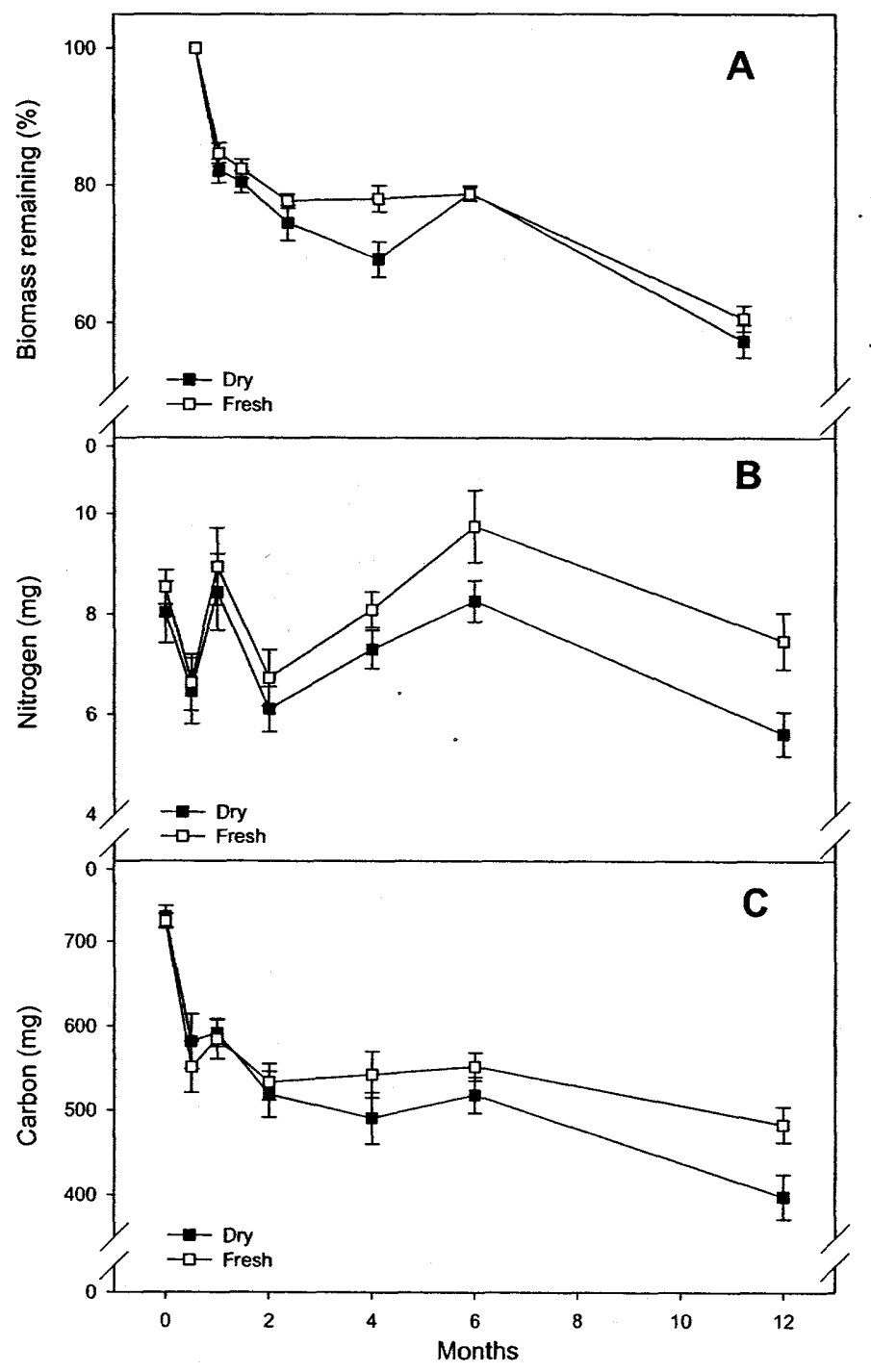

\section{Initial condition}

Roots that were dried prior to decomposition had a faster rate of mass loss ( $b$ in eq. 1 and Table 1 ) and a greater mass loss after 12 months of in situ decomposition, even though mass loss at individual time periods was not significantly different (Fig. 3A). Model depictions of decomposition (Table 1) indicate significant differences in rate of loss of $\mathrm{C}, \mathrm{K}$, $\mathrm{Ca}, \mathrm{Mg}$, and mass between dried and fresh root tissues. $\mathrm{Al}$ though initial condition (hydration) of fine roots did not affect initial nutrient contents ( $a$ in eq. 1 and Table 1), after 1 year of in situ decomposition, dried roots contained approximately $20 \%$ less N (Fig. 3B), C (Fig. 3C), K (Fig. 4A), $\mathrm{Ca}$ (Fig. 4B), and $\mathrm{Mg}$ (Fig. 4C) than fresh roots. $\mathrm{P}$ (not shown) was the only measured nutrient that did not significantly respond to initial root moisture condition.
Fig. 4. Mean contents of (A) potassium, (B) calcium, and (C) magnesium in loblolly pine roots decomposing in situ over a 12-month period. Soil fertilization treatments and root size class have been averaged by initial condition. Error bars represent one standard deviation, and each data point represents $n=12$.

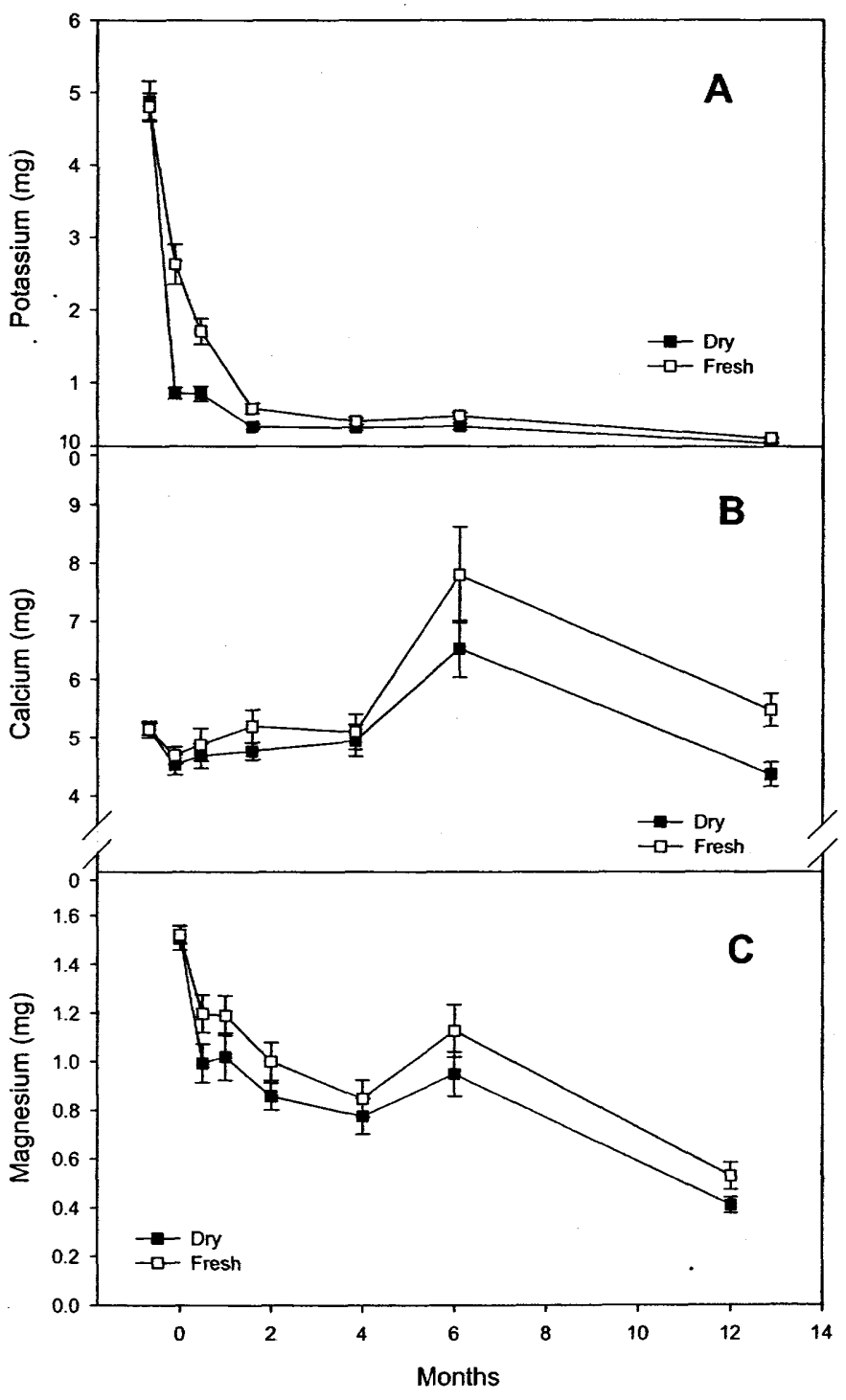

An interaction between initial condition and root size (Table 1$)$ indicates that previously dried very fine roots $(0-2 \mathrm{~mm})$ lost biomass more rapidly than very fine fresh roots, which lost biomass more rapidly than previously dried fine roots $(2-5 \mathrm{~mm})$, followed by fresh fine roots.

\section{Discussion and conclusions}

Results from this work indicate significantly different mass and nutrient loss from roots that were initially hydrated compared with roots that were oven-dried. Dried roots lost mass and nutrients faster than fresh roots, and the initial pulses in $\mathrm{P}, \mathrm{K}, \mathrm{Ca}$, and mass loss were significantly greater for dried roots than for fresh roots. These results disagree with the suggestion that decay of washed and dried samples was slow because microbial populations had to recover (Ruark 1993) after the loss of root exudates and retardation of microbial 
activity (Killham 1994). In the absence of chemical differences associated with drying roots prior to decomposition, physical changes in cell wall and epidermal continuity are likely conduits for increased leaching of nutrients from dried roots.

As expected, very fine roots decomposed faster than fine roots. Initial decomposition rate was also faster for very fine than for fine roots in a beech forest $(50 \%-54 \%$ vs. $70 \%-79 \%$ after 1 month) (Judas et al. 1995). The ratio of nonstructural to structural mass is much higher in small roots (Boot 1990), and the inverse relationship between root diameter and decay could be explained by the positive linear relationship between lignin content and root diameter. However, the relatively short duration of this study may only mimic early (controlled by nutrients) decomposition (Berg 1984) and may not provide indications of multiple-stage or long-term decomposition of more lignified materials.

Concentrations and contents of $\mathrm{N}, \mathrm{P}, \mathrm{K}, \mathrm{Ca}$, and $\mathrm{Mg}$, but not $\mathrm{C}$, were higher in very fine roots than in fine roots. Similar findings were reported for $\mathrm{N}, \mathrm{P}, \mathrm{S}$, and $\mathrm{Mg}$, but not $\mathrm{C}$, in Scots pine (Pinus sylvestris L.) roots (Berg 1984; Gordon and Jackson 2000). Our results agree with increased retention of $\mathrm{N}$ and $\mathrm{P}$ reported with increased root diameter (Fahey et al. 1988) and greater release of all measured nutrients from smaller diameter roots than from larger diameter roots (King et al. 1997).

Although needle litter decomposition is often positively correlated with tissue $\mathrm{N}$ concentrations, especially during the initial decomposition phase (Pandy and Singh 1982; Hunt et al. 1988; Aber et al. 1990), this pattern has not been reported for root decomposition (Silva and Miya 2001) and was not apparent in this study. Even though our results support the inverse correlation between root diameter and nutrient concentrations, we could not correlate increased nutrient concentrations in roots from fertilized plots with increased decomposition rates. Other studies have reported that $\mathrm{N}$ additions decreased microbial biomass $\mathrm{C}$ and potential microbial activity in pine stands (Compton et al. 2004), thereby potentially decreasing the decomposition potential. However, decomposition rates do not vary systematically among sites of different soil nutrient levels (Laiho et al. 2004), and they most likely were not affected by the sandy soil with a low nutrient holding capacity in our study.

Fertilization did result in higher nutrient concentrations in decomposing roots, and hence larger nutrient pools, than in roots from control plots. Rates of $\mathrm{N}$ and $\mathrm{P}$ release from pine roots were significantly faster from fertilized roots than from controls and may be related to the differences in initial $\mathrm{C} / \mathrm{N}$ values (69 and 112 for fertilized and control roots, respectively). Root Ca concentration was not linked to differences in mass loss or nutrient release rates in this study. The reduction in decomposition and the relative stability of nutrient concentrations noted between months 2 and 6 (September through January) could likely be explained by the decreasing ambient temperatures.

Fitting of exponential response curves enabled comparison of the coefficients of variables to specifically test for differences in initial nutrient concentrations or content and decomposition. Results from Mun and Whitford (1998) and King et al. (1997) utilizing dry roots suggest that decay of roots $<5 \mathrm{~mm}$ is not impacted by exogenous sources of nutri- ents. However, results from this study clearly indicate fertilization increases $\mathrm{N}$ and $\mathrm{P}$ release. The discrepancies between results from King et al. (1997) and those of this study most likely result from the statistical methods used. King et al. (1997) calculated nutrient indexes at individual collection times and compared decay rate constants. In this study, the coefficients of variables from individual nutrient and mass loss response curves were compared, enabling a more sensitive evaluation.

This direct comparison of fresh and dried roots indicates that the rate of nutrient loss is influenced by the condition of a root when it begins to decompose, and that decomposition in situ is likely a slower process than previously believed. The rate and extent of biomass decay. and the associated release of $\mathrm{N}, \mathrm{C}, \mathrm{Ca}, \mathrm{P}$, and $\mathrm{K}$ are significantly slower and of lower magnitudes when roots remain hydrated before decomposition begins than when roots are oven-dried before decomposition.

\section{Acknowledgements}

The authors acknowledge Mark Coleman, Richard Birdsey, Coeli Hoover, and Felipe Sanchez for their early reviews of this manuscript. The authors also extend thanks to several anonymous reviewers and to Karen and Laura Sarsony for their time.

\section{References}

Aber, J.D., Melillo, J.M., and McClaugherty, C.A. 1990. Predicting long term pattern of mass loss, nitrogen dynamics and soil organic matter formation from fine litter chemistry in temperate forest ecosystems. Can. J. Bot. 68: 2201-2269.

Aerts, R. 1990. Nutrient use efficiency in evergreen and deciduous species from heath lands. Oecologia, 84: 391-397.

Albaugh, T.J., Allen, H.L., Dougherty, P.M., Kress, L.W., and King, J.S. 1998. Leaf area and above- and belowground growth responses of loblolly pine to nutrient and water additions. For. Sci. 44: 317-328.

Berg, B. 1984. Decomposition of root litter and some factors regulating the process: long term root litter decomposition in a Scots pine forest. Soil Biol. Biochem. 16: 609-617.

Bloomfield, J., Vogt, K.A., and Vogt, D.J. 1993. Decomposition rates and substrate quality and foliage of two tropical tree species in the Luquillo Experimental Forest, Puerto Rico. Plant Soil, 150: 233-245.

Boot, R.G.A. 1990. The significance of size and morphology of root systems for nutrient acquisition and competition. In Causes and consequences of variation in growth rate and productivity of higher plants. Edited by H. Lambers, M.L. Cambridge, H. Lonings, and T.L. Pons. SPB Academic Publishing, The Hague, Netherlands. pp. 299-311.

Compton, J.E., Watrud, L.S., Porteous, L.A., and DeGrood, S. 2004. Response of soil microbial biomass and community competition to chronic nitrogen additions at Harvard Forest. For. Ecol. Manage. 196: 143-158.

Fahey, T.J., Hughes, J.W., Pu, M., and Arthur, M.A. 1988. Root decomposition and nutrient flux following whole-tree harvest of northern hardwood forest. For. Sci. 34: 744-768.

Fogel, R.M., and Hunt, G.A. 1983. Contribution of mycorrhizae and soil fungi to nutrient cycling in a Douglas-fir ecosystem. Can. J. For. Res. 13: 219-232. 
Gordon, W.S., and Jackson, R.B. 2000. Nutrient concentration in fine roots. Ecology, 81: 275-280.

Hendrick, R.L., and Pregitzer, K.S. 1993. Patterns of fine root mortality in two maple forests. Nature (London), 361: 59-61.

Hunt, H.W., Ingham, E.R., Coleman, D.C., Elliott, E.T., and Reid, C.P.P. 1988. Nitrogen limitation' of production and decomposition in prairie, mountain meadow, and pine forest. Ecology, 69: 1009-1016.

Joslin, J.D., and Hendersen, G.S. 1987. Organic matter and nutrients associated with fine root turnover in a white oak stand. For. Sci. 33: 330-346.

Judas, M., Gobel, M., and Schauermann, J. 1995. Mass loss of Urtica dioica $\mathrm{L}$. roots in a beech forest as affected by soil fauna and soil type. Pedobiologia, 39: 528-537.

Killham, K. 1994. Soil ecology. Cambridge University Press, Cambridge, UK.

King, J.S., Allen, H.L., Dougherty, P.M., and Strain, B.R. 1997. Decomposition of roots in loblolly pine: effects of nutrient and water availability and root size class on mass loss and nutrient dynamics. Plant Soil, 195: 171-184.

Laiho, R., Laine, J., Trettin, C., and Finer, L. 2004. Scots pine litter decomposition along drainage succession and soil nutrient gradients in peatland forests, and the effects of inter-annual weather variation. Soil Biol. Biochem. 36: 1095-1109.

McClaugherty, C.A., Aber, J.D., and Melillo, J.M. 1982. The role of fine roots in the organic matter and nitrogen budgets of two forested ecosystems. Ecology, 63: 1481-1490.

Meier, C.E., Grier, C.C., and Cole, D.W. 1985. Below- and aboveground $\mathrm{N}$ and $\mathrm{P}$ use by Abies amabilis stands. Ecology, 66: 1928-1942.

Mun, H.T., and Whitford, W.G. 1998. Changes in mass and chemistry of plant roots during the long-term decomposition on a Chihuahuan desert watershed. Biol. Fertil Soils, 26: 16-22.

Nambiar, E.K.S. 1987. Do nutrients retranslocate from fine roots? Can. J. For. Res. 17: 913-918.
Nambiar, E.K.S., and Fife, D.F. 1991. Nutrient retranslocation in temperate conifers. Tree Physiol. 9: 185-207.

Pandy, C.B., and Singh, J.S. 1982. Leaf litter decomposition in an oak-conifer forest in Himalaya: the effects of climate and chemical composition. Forestry, 55: 47-59.

Persson, H. 1979. Fine root production, mortality and decomposition in forest ecosystems. Vegetatio, 41: 101-109.

Raich, J.W., and Nadelhoffer, K.J. 1989. Belowground carbon allocation in forest ecosystems: global trends. Ecology, 70: 1346-1354.

Ruark, G.A. 1993. Modeling soil temperature effects on in situ decomposition rates for fine roots of loblolly pine. For. Sci. 39: 118-129.

SAS Institute Inc. 1985. SAS/STATTM guide for personal computers, version 6 ed. SAS Institute Inc., Cary, N.C.

Silva, W.L., and Miya, R.K. 2001. Global patterns in root decomposition: comparisons of climate and litter quality effects. Oecologia, 129: 407-419.

Van Lear, D.H., and Kapeluck, P.R. 1995. Above- and below-ground stump biomass and nutrient content of a mature loblolly pine plantation. Can. J. For. Res. 25: 361-367.

Vogt, K.A., Grier, C.C., Meier, C.E., and Edmonds, R.L. 1982. Mycorrhizal role in net primary production and nutrient cycling in Abies amabilis ecosystems in western Washington. Ecology, 63: $370-380$.

Vogt, K.A., Vogt, D.J., and Bloomfield, J. 1991. Input of organic matter to the soil by tree roots. In Proceedings of the ISSR Symposium on Development in Agriculture and Managed Forest Ecology, Uppsala, Sweden, 1988. Edited by B.L. McMichael and H. Persson. Elsevier, New York. pp. 171-190.

Wells, C.G., Jorgensen, J.R., and Burnette, C.E. 1975. Biomass and mineral elements in a thinned loblolly pine plantation. USDA For. Serv. Res. Paper SE-126.

Yavitt, J.B., and Fahey, T.J. 1982. Loss of mass and nutrient changes of decaying woody roots in lodgepole pine forests, southeastern Wyoming. Can J. For Res. 12: 745-752. 
